\title{
PENGEMBANGAN PERANGKAT PEMBELAJARAN IPA BIOLOGI KELAS VII SMP NEGERI 27 SUNGAI ANDAI BANJARMASIN BERBASIS INQUIRY TERBIMBING
}

\author{
Rabiatul Adawiyah ${ }^{1}$, Yulianti Hidayah ${ }^{2}$
}

\section{Program Studi Pendidikan Biologi STKIP-PGRI Banjarmasin adawiyahr567gmail.com (081348013931)}

2. Program Studi Pendidikan Biologi STKIP-PGRI Banjarmasin yuliantihidayah@yahoo.com (085345617823)

\begin{abstract}
ABSTRAK
Penggunaan perangkat yang baik akan memandu pelaksanaan pembelajaran yang berkualitas sesuai dengan harapan, terutama proses yang baik dapat meningkatkan hasil yang baik. Penelitian ini bertujuan untuk mengetahui tingkat kevalidan, kepraktisan dan keefisienan perangkat pembelajaran IPA Biologi Kelas VII berbasis Inquiry Terbimbing yang layak untuk digunakan dalam kegiatan pembelajaran oleh guru di sekolah. Jenis penelitian ini berupa penelitian pengembangan (Researce and Development) menggunakan prosedur penelitian pengembangan yang telah dimodifikasi dari Sugiyono (2009). Perangkat yang dikembangkan berupa silabus , RPP, LKS dan Lembar Penilaian pada konsep 'Pencemaran Lingkungan'. Langkah uji coba produk meliputi uji perorangan, uji kelompok kecil, dan uji lapangan. Teknik pengumpulan data dalam penelitian ini adalah, 1) instrumen validasi pakar untuk mengetahui kevalidan perangkat pembelajaran. 2) lembar observasi keterlaksanaan pembelajaran berbasis inkuiri terbimbing dan angket respon siswa untuk menegtahui keparaktisan perangkat pembelajaran. dan 3) tes hasil belajar kognitif dan keterampilan proses sains siswa untuk mengetahui keefektifan perangkat pembelajaran. Teknik analisis data dilakukan secara deskriptif kualitatif dan kuantitatif terdiri dari validitas, kepraktisan, dan keefektifan perangkat pembelajaran. Hasil Penelitian ini adalah 1) validitas perangkat pembelajaran dalam kategori cukup valid, 2) kepraktisan perangkat pembelajaran dalam kategori praktis, dan 3) keefektifan perangkata pembelajaran dalam kategori efektif. Ini bererti perangkat pembelajaran yang dikembangkan memenuhi kriteria valid namun perlu direvisi kecil, praktis, dan efektif serta dapat digunakan dalam pembelajaran.
\end{abstract}

Kata Kunci: Pengembangan, Perangkat pmbelajaran, Inquiry Terbimbing

\section{PENDAHULUAN}

Menurut Kemendikbud (2013) di dalam pembelajaran peserta didik didorong untuk menemukan sendiri dan mentransformasikan informasi kompleks, mengecek informasi baru dengan infromasi yang sudah ada dalam ingatannya. Dalam pembelajaran di kelas siswa melakukan pembelajaran dengan mengamati, menanya, mengumpulkan informasi, mengasosiasi atau menganalisis, dan mengkomunikasikan apa yang sudah ditemukan dalam kegiatan analisis. 
Biologi sebagai bagian dari sains dalam pembelajarannya seharusnya tidak lepas dari hakekat sains (nature of science) yang meliputi pengembangan kemampuan berfikir (mind on), keterampilan (hand on) dan sikap (heart on).

Seorang pendidik sering dihadapkan pada berbagai masalah, terutama dalam proses pembelajaran. Permasalahan yang timbul disebabkan oleh berbagai hal misalnya, kurangnya inovasi guru ketika melakukan pembelajaran di kelas, kurangnya penggunaan media, kurangnya pemilihan strategi yang tepat dan benar, tidak adanya model-model pembelajaran yang menimbulkan minat belajar siswa, tidak adanya variasi tempat pelaksanaan pembelajaran, dan penentuan sistem penilaian yang kurang tepat. Berdasarkan observasi dan wawancara dengan guru mata pelajaran IPA Biologi di SMP Negeri 27 Sungai andai Banjarmasin, permasalahan yang dialami diantaranya adalah: 1) Perangkat pembelajaran yang dibuat untuk digunakan dalam pembelajaran belum dipersiapkan dengan baik, mulai dari perencanaan pembuatan silabus, RPP, bahan ajar, LKS, dan sistem penilaian. 2) Dalam pembelajaran guru hanya berorientasi pada materi pembelajaran dengan alasan tuntutan kurikulum untuk menghadapi ulangan umum atau ujian tengah semester dan akhir semester. Oleh karena itu, diperlukan upaya untuk melihat efektivitas suatu pendekatan dan metode pengajaran proses belajar mengajar yang dilakukan dapat berhasil dan memudahkan siswa dalam suatu disiplin ilmu atau mata pelajaran yang diterimanya.

Model pembelajaran inkuiri terbimbing diharapkan mengubah proses pengajaran yang cenderung tidak relevan dengan pola pendekatan atau metode pengajaran yang digunakan. Menurut Gulo (2002, dalam Trianto, 2009:135-137) model inkuiri adalah suatu model dalam kegiatan pembelajaran yang melibatkan secara maksimal seluruh kemampuan siswa untuk mencari dan menyelidiki secara sistematis, kritis, logis, analitis, sehingga siswa dapat merumuskan sendiri penemuannya dengan percaya diri. Pembelajaran inkuiri dirancang untuk mengajak siswa secara langsung ke dalam proses ilmiah dalam waktu yang relatif singkat. yang bermula dari merumuskan masalah, merumuskan hipotesis, mengumpulkan data, menganalisis data, dan membuat kesimpulan.

Untuk meningkatkan kualitas pembelajaran dan mengoptimalkan efektivitas proses pembelajaran, maka guru perlu melakukan terobosan dan langkah-langkah untuk mengatasi permasalahan yang dihadapi. Salah satunya dengan melakukan pengembangan perangkat pembelajaran berkarakter berbasis inquiry terbimbing. Melalui pengembangan perangkat pembelajaran yang baik diharapkan mampu memberikan kesempatan kepada siswa untuk menggali pengetahuan yang akan didiskusikan di kelas, memberikan kesempatan interaksi siswa dengan siswa, dan siswa dengan guru dalam diskusi kelompok. Selain itu pembelajaran ini memberikan kontribusi yang positif pada siswa dalam hal memperoleh pemahaman, meningkatkan interaksi dan partisipasi, dan mengembangkan karakter positif siswa. Penggunaan perangkat yang baik akan memandu pelaksanaan pembelajaran yang berkualitas sesuai dengan harapan, terutama proses yang baik dapat meningkatkan hasil yang baik. Penelitian pengembangan ini bertujuan untuk mengetahui tingkat kevalidan, kepraktisan dan keefisienan perangkat pembelajaran IPA Biologi Kelas VII berbasis Inquiry Terbimbing yang layak untuk digunakan dalam kegiatan pembelajaran oleh guru di sekolah. 


\section{METODE PENELITIAN}

Jenis penelitian ini berupa penelitian pengembangan (Researce and Development). Penelitian dilakukan menggunakan prosedur penelitian pengembangan yang telah dimodifikasi dari Sugiyono (2009). Prosedur penelitian dapat dilihat pada Gambar 1 berikut.

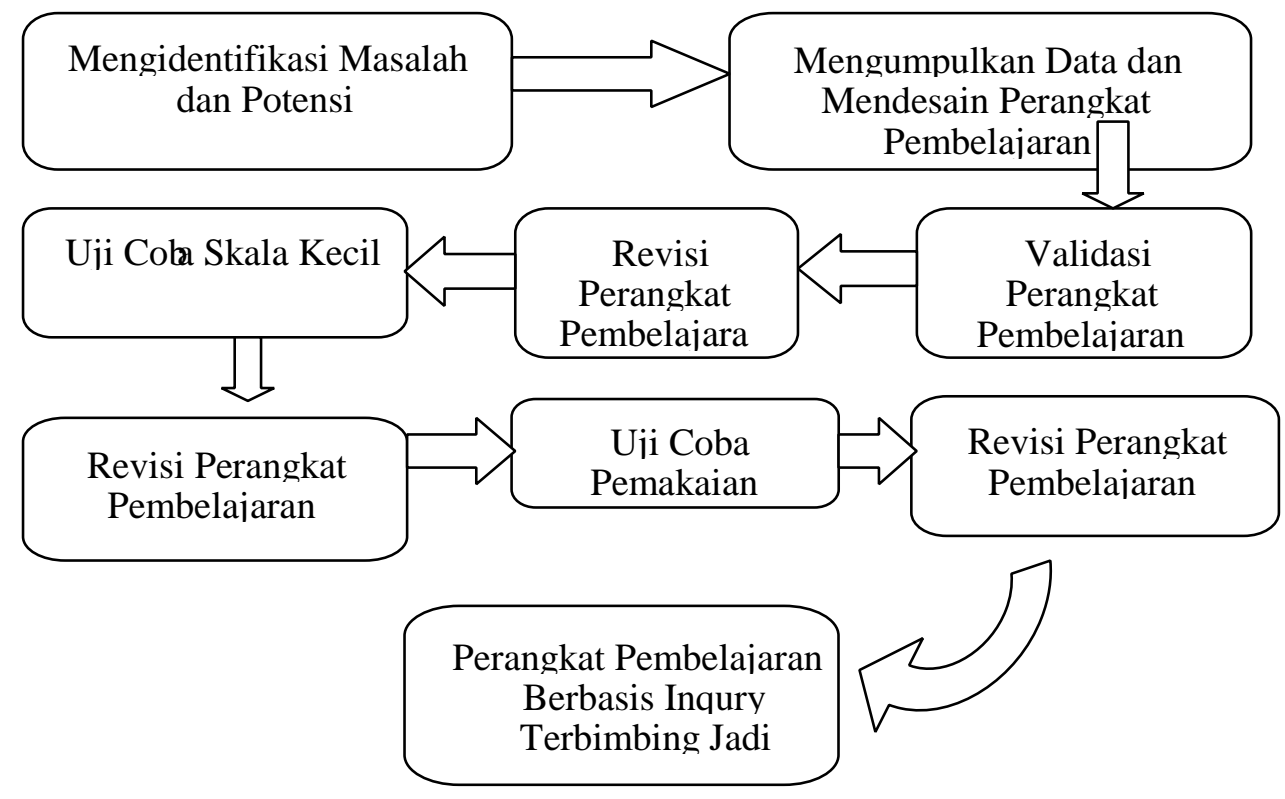

Gambar 1. Tahapan Pengembangan Perangkat

Pembelajaran IPA Biologi Berbasis Inkuiri

Terbimbing.

Uji validasi perangkat pembelajaran dilakukan oleh 2 orang validator . Hasil penilaian terhadap perangkat pembelajaran digunakan untuk memperbaiki kekurangan sehingga perangkat pembelajaran yang dihasilkan layak digunakan dalam pembelajaran. Kepraktisan perangkat pembelajaran diperoleh berdasar uji perseorangan terhadap keterbacaan LKS, keterlaksanaan RPP dan respon siswa terhadap kegiatan pembelajaran. Uji perorangan dan uji kelompok kecil dilakukan oleh 15 orang siswa kelas VIIB. Uji lapangan sebanyak 35 siswa kelas VIIC untuk menentukan keefektifan perangkat pembelajaran. Penelitian pengembangan ini dilaksanakan selama 6 bulan ( Maret-Agustus 2016) di SMP Negeri 27 Sungai Andai Banjarmasin.

Jenis Data dan instrument untuk menetapkan kevalidan perangkat pembelajaran diperoleh melalui lembar validasi catatan pakar menggunakan instrument penilaian silabus, RPP, LKS dan lembar penilaian. Keterbacaan diperoleh dari pendapat siswa tentang LKS yang dikumpulkan melalui angket. Kepraktisan perangkat pembelajaran diperoleh dari keterlaksanaan RPP berbasis inquiri terbimbing dan angket respon siswa. Keefektifan perangkat pembelajaran diperoleh dari hasil penilaian Keterampilan proses sains dan tes kognitif (pretes dan postes) menggunakan tes pilihan ganda.

Data yang diperoleh dianalisis secara deskriftif kualitatif dan kuantitatif. Data validitas perangkat pembelajaran dianalisis menurut Akbar (2013) 
menggunakan kategori "sangat valid" (dapat dipergunakan tanpa revisi), "valid" (dapat digunakan namun perlu revisi kecil ), "kurang valid"( disarankan tidak dipergunakan karena perlu revisi besar-besaran), "tidak valid" ( tidak boleh dipergunakan, dan perlu revisi besar-besaran), "sangat tidak valid" (tidak boleh dipergunakan).

Data uji keterbacaan LKS dianalisis secara deskriftif. Data keterlaksanaan RPP dianalisis menggunakan persentase kualifikasi kinerja guru menurut Kunandar (2013) dengan kategori "sangat baik", "baik", "cukup", dan "kurang." Data respon siswa dianalisis secara deskriftif dengan menggunakan persentase atas tanggapan siswa.

Data hasil belajar kognitif (pretes -postes) dan keterampilan proses sains siswa dianalisis berdasarkan Kemendikbud, (2015) dengan kategori "A" (sangat baik), "B" (baik), "C" (cukup), dan "D” (kurang).

\section{HASIL DAN PEMBAHASAN}

\section{A. Hasil}

\section{Tingkat validitas perangkat pembelajaran}

Tingkat validitas perangkat pembelajaran diperoleh berdasarkan hasil validasi perangkat pembelajaran yang dilakukan oleh tim ahli. Perangkat pembelajaran konsep pencemaran lingkungan ini dinilai kevalidannya oleh 2 orang tim ahli yang telah ditetapkan. Setelah itu direvisi sesuai saran validator . Rekapitulasi hasil validitas perangkat pembelajaran hasil pengembangan tertera pada Tabel 1 berikut :

Tabel 1. Rekapitulasi Validasi Perangkat Pembelajaran oleh Pakar/Tim ahli terhadap Perangkat Pembelajaran Hasil Pengembangan.

\begin{tabular}{|l|l|l|l|}
\hline $\begin{array}{l}\text { Perangkat } \\
\text { Pembelajaran }\end{array}$ & $\begin{array}{l}\text { Skor rata- } \\
\text { rata } \\
\text { validasi }\end{array}$ & $\begin{array}{l}\text { Kriteria } \\
\text { validitas }\end{array}$ & Saran Validator \\
\hline $\mathbf{( 1 )}$ & $\mathbf{( 3 )}$ & $\mathbf{4})$ & $\mathbf{( 5 )}$ \\
\hline Silabus & $81,76 \%$ & $\begin{array}{l}\text { valid, atau } \\
\text { dapat } \\
\text { digunakan } \\
\text { namun perlu } \\
\text { direvisi kecil 1 }\end{array}$ & $\begin{array}{l}\text { Lengkapi kegiatan } \\
\text { pembelajaranan dengan } \\
\text { keterampilan proses } \\
\text { sains yang akan diteliti. } \\
\text { Sesuaikan waktu } \\
\text { dengan keselesaian } \\
\text { langkah dan tugas } \\
\text { pembelajaran }\end{array}$ \\
\hline RPP & $79,76 \%$ & $\begin{array}{l}\text { valid, atau } \\
\text { dapat } \\
\text { digunakan } \\
\text { namun perlu } \\
\text { direvisi kecil }\end{array}$ & $\begin{array}{l}\text { - Tujuan Pembelajaran } \\
\text { perlu dlengkapi. } \\
\text { Kaloborasi Fase model } \\
\text { pembelajaran } \\
\text { ditempatkan sesuai } \\
\text { dengan kegiatan yang } \\
\text { dilakukan. }\end{array}$ \\
\hline
\end{tabular}




\begin{tabular}{|c|c|c|c|}
\hline & & & $\begin{array}{l}\text { - Pertimbangkan alokasi } \\
\text { waktu dengan } \\
\text { kegiatan }\end{array}$ \\
\hline LKS & $76,56 \%$ & $\begin{array}{l}\text { valid, atau } \\
\text { dapat } \\
\text { digunakan } \\
\text { namun perlu } \\
\text { direvisi kecil }\end{array}$ & $\begin{array}{l}\text { - Cantumkan KD \& } \\
\text { tujuan pembelajaran } \\
\text { - Tuliskan setiap } \\
\text { indikator } \\
\text { keterampilan proses } \\
\text { sains yang akan } \\
\text { dikerjakan. } \\
\text { - Wacana dilengkapi } \\
\text { gambar yang menarik } \\
\text { dan sesuai. } \\
\text { - Petunjuk pengerjaan } \\
\text { LKS harus jelas. } \\
\end{array}$ \\
\hline $\begin{array}{l}\text { LP Kognitif } \\
\text { Produk }\end{array}$ & $75 \%$ & $\begin{array}{l}\text { valid, atau } \\
\text { dapat } \\
\text { digunakan } \\
\text { namun perlu } \\
\text { direvisi kecil }\end{array}$ & $\begin{array}{l}\text { - Sebaiknya soal } \\
\text { menggunakan pilihan } \\
\text { ganda agar lebih } \\
\text { efektif. }\end{array}$ \\
\hline $\begin{array}{l}\text { LP } 6 \\
\text { Keterampilan } \\
\text { Proses sains }\end{array}$ & $75 \%$ & $\begin{array}{l}\text { valid, atau } \\
\text { dapat } \\
\text { digunakan } \\
\text { namun perlu } \\
\text { direvisi kecil }\end{array}$ & $\begin{array}{l}\text { Tambahkan dengan } \\
\text { gambar yang sesuai } \\
\text { indikator soal. }\end{array}$ \\
\hline
\end{tabular}

Keterangan :

Sangat valid, atau dapat digunakan tanpa revisi (81-100\%), valid atau dapat digunakan namun perlu direvisi kecil (61-80\%), Kurang valid atau disarankan jangan dipergunakan karena perlu revisi besar-besaran (41$60 \%$ ), Tidak valid, atau tidak boleh digunakan dan perlu revisi besarbesaran $(21-40 \%)$.

\section{Kepraktisan perangkat pembelajaran}

Kepraktisan perangkat pembelajaran diperoleh berdasar uji perseorangan terhadap keterbacaan LKS, keterlaksanaan RPP dan respon siswa terhadap kegiatan pembelajaran. Hasil yang didapatkan pada uji keterbacaan LKS disajikan pada Tabel 2 berikut.

Tabel 2. Hasil uji keterbacaan perangkat LKS pada uji perseorangan (One-to-One Evaluation)

\begin{tabular}{|c|c|c|c|}
\hline $\begin{array}{c}\text { Aspek } \\
\text { Penilaian }\end{array}$ & Kriteria & Jumlah & Prosentase \\
\hline 1. Isi LKS & $\mathrm{Mn}$ & 13 & $87 \%$ \\
\cline { 2 - 4 } & $\mathrm{Tm}$ & 2 & $13 \%$ \\
\hline 2. Tampilan & $\mathrm{Mn}$ & 13 & $87 \%$ \\
\hline
\end{tabular}


Adawiyah R. \& Hidayah, Y. / LENTERA Jurnal Ilmiah Kependidikan Vol.12 No.1 (2017) 72-84

\begin{tabular}{|c|c|c|c|}
\cline { 2 - 4 } LKS & $\mathrm{Tm}$ & 2 & $13 \%$ \\
\hline \multirow{3}{*}{$\begin{array}{c}\text { 3. Penjelasan } \\
\text { LKS }\end{array}$} & $\mathrm{Ab}$ & 0 & $0 \%$ \\
\cline { 2 - 4 } & $\mathrm{As}$ & 14 & $93 \%$ \\
\cline { 2 - 4 } & $\mathrm{Ta}$ & 1 & $0,7 \%$ \\
\hline \multirow{2}{*}{$\begin{array}{c}\text { Kesulitan } \\
\text { Kalimat }\end{array}$} & $\mathrm{Ab}$ & 1 & $0,7 \%$ \\
\cline { 2 - 4 } & $\mathrm{As}$ & 14 & $93 \%$ \\
\cline { 2 - 4 } & $\mathrm{Ta}$ & 0 & $0 \%$ \\
\hline
\end{tabular}

Keterangan :

Mn : Menarik Tm : Tidak

menarik

$\mathrm{Ab}$ : Ada banyak

Md : Mudah dipahami, $\quad$ Sd :

Susah dipahami Ta : Tidak ada,

As : Ada sedikit

Data hasil pengamatan terhadap keterlaksanaan tahap pembelajaran berdasar aktivitas yang dilakukan oleh guru. Penilaian berdasar rubrik yang telah disediakan. Ringkasan hasil keterlaksanaan RPP disajikan pada Tabel 3 berikut.

Tabel 3. Rata-rata Aktivitas Guru Terhadap Keterlaksanaan Tahap Pembelajaran Pada Uji Pemakaian (Field Trial)

\begin{tabular}{|c|c|c|c|c|c|}
\hline \multirow{2}{*}{ No } & \multirow{2}{*}{ Kegiatan Guru } & \multicolumn{4}{|c|}{ Pertemuan } \\
\hline & & I & II & III & IV \\
\hline $\mathrm{A}$ & Kegiatan Pendahuluan & 3,4 & 3,3 & 3,5 & 3,8 \\
\hline \multirow[t]{7}{*}{$\mathrm{B}$} & $\begin{array}{l}\text { Kegiatan Inti } \\
\text { Sebelum kegiatan inti dimulai guru } \\
\text { menayangkan sedikit informasi }\end{array}$ & 3 & 3 & 3 & 4 \\
\hline & 1. Membimbing siswa merumuskan masalah & 3 & 3 & 4 & 4 \\
\hline & 2. Membimbing siswa merumuskan hipotesis & 2 & 3 & 3 & 4 \\
\hline & $\begin{array}{l}\text { 3. Membimbing siswa untuk mengamati } \\
\text { berbagai macam gambar yang berhubungan } \\
\text { dengan materi. }\end{array}$ & 3 & 3 & 4 & 4 \\
\hline & 4. Membimbing siswa mengumpulkan data & 2 & 3 & 3 & 4 \\
\hline & $\begin{array}{l}\text { 5. Membimbing siswa menguji hipotesis untuk } \\
\text { menganalisis hasil pengamatan dan } \\
\text { membandingkan pada literatur yang ada } \\
\text { untuk membuktikan hipotesis yang mereka } \\
\text { ajukan. }\end{array}$ & 2 & 3 & 3 & 3 \\
\hline & 6. Membimbing membuat kesimpulan & 3 & 3 & 3 & 4 \\
\hline
\end{tabular}




\begin{tabular}{|c|l|c|c|c|c|}
\hline C & Kegiatan Penutup & 2,8 & 3,3 & 3,7 & 3,8 \\
\hline & Nilai Pelaksanaan Pembelajaran & 76,04 & 80,20 & 87,5 & 94,79 \\
\hline \multirow{2}{*}{ Kategori } & C & B & B & SB \\
\hline
\end{tabular}

Keterangan :

Sangat Baik (91-100), Baik (81-90), Cukup (71-80), Kurang $(\leq 70)$.

Respon siswa terhadap pembelajaran adalah tanggapan yang diberikan siswa terhadap kegiatan pembelajaran yang berlangsung. Respon siswa dalam pembelajaran ringkasannya disajikan pada Tabel 4 berikut

Tabel 4. Respon Siswa terhadap Pembelajaran pada Uji Pemakaian (Field Trial)

\begin{tabular}{|c|c|c|c|}
\hline No & Soal Respon & $\mathrm{F}$ & $\%$ \\
\hline \multirow[t]{3}{*}{1.} & $\begin{array}{l}\text { Pendapat siswa mengenai LKS, cara guru mengajar, cara } \\
\text { belajar, dan proses pembelajaran }\end{array}$ & & \\
\hline & a. menyenangkan & 35 & 100 \\
\hline & b. tidak menyenangkan bahkan membosankan & 0 & 0 \\
\hline \multirow[t]{4}{*}{2.} & $\begin{array}{l}\text { Pendapat siswa mengenai LKS, cara guru mengajar, cara } \\
\text { belajar, dan proses pembelajaran }\end{array}$ & & \\
\hline & $\begin{array}{l}\text { a. Merupakan hal baru dan sangat membantu siswa dalam } \\
\text { belajar }\end{array}$ & 25 & 70 \\
\hline & $\begin{array}{l}\text { b.Merupakan hal yang tidak baru tetapi membantu siswa } \\
\text { dalam belajar }\end{array}$ & 10 & 30 \\
\hline & $\begin{array}{l}\text { c.Merupakan hal yang tidak baru dan tidak membantu } \\
\text { siswa dalam belajar }\end{array}$ & 0 & 0 \\
\hline \multirow[t]{4}{*}{3.} & $\begin{array}{l}\text { Kegiatan yang dilakukan selama berlangsungnya proses } \\
\text { belajar: }\end{array}$ & & \\
\hline & a.Dapat menyatakan pendapat untuk menjawab pertanyaan & 32 & 91 \\
\hline & $\begin{array}{l}\text { b.Dapat melakukan penyelidikan/pengamatan untuk } \\
\text { menjawab pertanyaan }\end{array}$ & 34 & 97 \\
\hline & $\begin{array}{l}\text { c.Berminat untuk mengikuti kegiatan belajar mengajar } \\
\text { seperti ini }\end{array}$ & 35 & 100 \\
\hline \multirow[t]{4}{*}{4.} & $\begin{array}{l}\text { Siswa dapat memahami dengan baik LKS atau buku-buku } \\
\text { sumber yang digunakan }\end{array}$ & & \\
\hline & a. Susah memahaminya & 0 & 0 \\
\hline & b. Kurang paham & 5 & 17 \\
\hline & c. Dapat memahaminya & 30 & 83 \\
\hline \multirow[t]{2}{*}{5.} & $\begin{array}{l}\text { Menurut siswa susunan kalimat, gambar atau tabel dalam } \\
\text { LKS atau buku-buku sumber yang digunakan: }\end{array}$ & & \\
\hline & a. Tidak baik & 0 & 0 \\
\hline
\end{tabular}




\begin{tabular}{|l|c|c|}
\hline b. Cukup baik & 0 & 0 \\
\hline f. Baik & 10 & 30 \\
\hline g. Sangat baik & 25 & 70 \\
\hline
\end{tabular}

\section{Efektifitas Perangkat Pembelajaran}

Keefektivan perangkat pembelajaran diperoleh berdasar hasil belajar pre test dan pos test, serta penilaian hasil keterampilan Proses Sains siswa. Hasil yang didapatkan disajikan pada Tabel 5 dan Tabel 6 berikut.

Tabel 5. Rekapitulasi Hasil Belajar kognitif Siswa Pada Uji Pemakaian (Field Trial)

\begin{tabular}{|c|c|c|c|c|c|}
\hline \multirow{2}{*}{$\begin{array}{c}\text { Hasil } \\
\text { Belajar }\end{array}$} & \multirow[b]{2}{*}{$\begin{array}{c}\text { Nilai } \\
\text { Rata- } \\
\text { rata }\end{array}$} & \multicolumn{2}{|c|}{ Hasil Belajar } & \multirow[b]{2}{*}{$\begin{array}{c}\text { Jumlah } \\
\text { Siswa }\end{array}$} & \multirow[b]{2}{*}{$\begin{array}{l}\text { Ketuntasan } \\
\text { Klasikal }(\%)\end{array}$} \\
\hline & & $\begin{array}{r}\text { Tuntas } \\
\text { (orang) }\end{array}$ & $\begin{array}{c}\text { Tidak } \\
\text { Tuntas } \\
\text { (orang) }\end{array}$ & & \\
\hline Pretes & 63,19 & 9 & 26 & \multirow{2}{*}{35} & 25,71 \\
\hline Postes & 93,19 & 35 & 0 & & 100 \\
\hline
\end{tabular}

Keterangan :

Sangat Baik $(\geq 87)$, Baik $(81 \leq$ nilai $<86)$, Cukup $(75 \leq$ nilai <81), Kurang $(<75)$.

Tabel 6. Rekapitulasi Nilai Keterampilan Proses Sains Siswa

\begin{tabular}{|c|c|c|c|c|c|c|c|c|}
\hline \multirow[t]{2}{*}{ No } & \multirow[t]{2}{*}{ Indikator } & \multicolumn{4}{|c|}{ Pertemuan } & \multirow[t]{2}{*}{ Skor } & \multirow{2}{*}{$\begin{array}{l}\text { Rata- } \\
\text { Rata }\end{array}$} & \multirow[t]{2}{*}{ Kategori } \\
\hline & & I & II & III & IV & & & \\
\hline 1. & $\begin{array}{l}\text { Melakukan } \\
\text { pengamatan }\end{array}$ & 79 & 83 & 88 & 92 & 342 & 85.5 & Baik \\
\hline 2. & $\begin{array}{l}\text { Merumuskan } \\
\text { masalah }\end{array}$ & 75 & 79 & 83 & 92 & 329 & 83,5 & Baik \\
\hline 3. & Membuat hipotesis & 71 & 75 & 79 & 83 & 308 & 77 & Cukup \\
\hline 4. & $\begin{array}{l}\text { Mengumpulkan } \\
\text { data }\end{array}$ & 75 & 83 & 83 & 88 & 329 & 82.25 & Baik \\
\hline 5. & Menganalisa data & 67 & 75 & 79 & 83 & 304 & 77 & Cukup \\
\hline 6. & $\begin{array}{l}\text { Membuat } \\
\text { Kesimpulan }\end{array}$ & 75 & 83 & 88 & 88 & 334 & 83.5 & Baik \\
\hline \multicolumn{2}{|c|}{ Rata-rata } & 73,66 & 80 & 83 & 87 & & & \\
\hline \multicolumn{2}{|c|}{ Kategori } & $\mathbf{K}$ & $\mathbf{C}$ & $\mathbf{B}$ & $\mathbf{B}$ & & & \\
\hline
\end{tabular}




\section{PEMBAHASAN}

\section{A. Kevalidan perangkat pembelajaran}

Hasil analisis data validitas perangkat pembelajaran oleh validator setelah dikonversikan pada Tabel konversi kevalidan diperoleh bahwa perangkat pembelajaran IPA Biologi berbasis inkuiri terbimbing termasuk kriteria valid dengan revisi kecil dan dapat digunakan.

Beberapa saran yang diberikan oleh validator, diantaranya yaitu memperjelas indikator pada silabus dan RPP. penambahan gambar/ilustrasi yang lebih menarik dan membuat langkah pada LKS yang lebih mengarah pada keterampilan proses sains dan mendukung kinerja proses pada LKS, serta melengkapi rubrik penilaian pada lembar penilaian. Saran-saran tersebut menjadi bahan pertimbangan untuk melakukan revisi. Collins, Joseph \& Bielaczyc (2004) dalam Listariyani (2016) mengemukakan bahwa desain penelitian dikembangkan untuk menyempurnakan desain penelitian sebelumnya dan terus melakukan revisi sehingga diperoleh produk yang baik.

Sejalan dengan Akbar (2013) yang menyatakan bahwa perangkat pembelajaran dapat dikatakan valid jika perangkat tersebut memiliki kesesuaian dengan landasan teoritik pengembangannya dan jika digunakan maka dapat mengukur kemampuan yang diharapkan. Ellis \& Levy (2010) menambahkan bahwa perangkat yang valid dapat memberikan perbedaan yang signifikan dengan pembelajaran menggunakan perangkat konvensional.

Berdasarkan hal tersebut maka dapat disimpulkan bahwa perangkat pembelajaran yang dikembangkan tergolong cukup valid. Meskipun demikian, perangkat pembelajaran tersebut dapat digunakan pada tahap ujicoba lapangan setelah dilakukan revisi kecil agar sesuai dengan saran-saran validator dan relevan dengan Kemendikbud No 53 Tahun 2015.

Penelitian dan pengembangan yang dilakukan di SMP Negeri 27 Banjarmasin telah menghasilkan perangkat pembelajaran berbasis inkuiri terbimbing pada konsep Pencemaran Lingkungan. Perangkat ini telah divalidasi oleh ahli dan diujikan pada siswa kelompok kecil kelas VII B dan uji lapangan kelas VII C. Hasil validasi menunjukkan kriteria valid dan bisa digunakan namun perlu direvisi kecil.

\section{B. Kepraktisan perangkat pembelajaran}

Hasil analisis uji keterbacaan bahan ajar dan LKS menunjukkan respons yang positif dari siswa. Hampir seluruh poin pertanyaan tentang keterbacaan bahan ajar direspons secara positif . Poin pertanyaan yang direspon secara positif oleh siswa yaitu poin 1 yaitu hasil keterbacaan LKS menunjukkan semua poin pertanyaan yang diberikan direspon secara positif sesuai dengan harapan peneliti. Secara lebih ringkas yaitu, poin 1 (isi LKS menarik), poin 2 (penampilan LKS menarik), poin 3 (uraian mudah dipahami), dan poin 4 (ilustrasi/gambar mudah dipahami).

Berdasarkan hal tersebut, maka dapat disimpulkan bahwa siswa memberikan respons positif terhadap LKS. Hal demikian berarti bahwa LKS "layak" dan direkomendasikan untuk digunakan dalam kegiatan pembelajaran. Meskipun demikian, LKS tetap direvisi kecil agar sesuai dengan karakteristik siswa dan kondisi sekolah yang menjadi tempat penelitian. Sinambela (2005) 
menyatakan bahwa melalui uji keterbacaan maka akan diketahui pemahaman siswa terhadap bahasa yang digunakan dalam perangkat pembelajaran. Senada dengan Nur (2013) yang menjelaskan bahwa tujuan uji perorangan yaitu untuk membetulkan kesalahan ketik, kalimat tidak jelas, petunjuk yang hilang atau tidak jelas, contoh yang tidak sesuai, kosa kata yang tidak dikenal, salah gambar atau halaman, dan gambar yang tidak komunikatif.

Hasil analisis keterlaksanaan RPP pada uji lapangan menunjukkan bahwa perangkat pembelajaran menggunakan model inkuiri terbimbing dapat mendorong keterlaksanaan RPP dengan rata-rata kategori "baik" pada ketiga tahapan RPP (pendahuluan, inti dan penutup). Hal demikian dapat diartikan bahwa KBM yang berlangsung telah berjalan sesuai dengan perencanaan yang terdapat pada RPP. Menurut Sudjana (2011), kemampuan yang dituntut dalam pelaksanaan proses belajar mengajar adalah keaktifan guru dalam menciptakan dan menumbuhkan kegiatan belajar sesuai dengan rencana yang telah disusun. Akbar (2013) menambahkan bahwa pembelajaran yang baik dilakukan secara interaktif, inspiratif, menyenangkan, menantang dan memotivasi siswa untuk berpartisipasi aktif serta memberikan ruang yang cukup bagi prakarsa, kreativitas, dan kemandirian sesuai bakat, minat dan perkembangan fisik dan psikologis siswa. Keterlaksanaan RPP didasarkan atas pengelolaan kegiatan belajar mengajar. Dewi,dkk (2013) menyatakan bahwa hasil kepraktisan perangkat pembelajaran ditunjukkan oleh kemudahan perangkat pembelajaran ini diimplementasikan di kelas dan dipergunakan oleh guru dan siswa.

Berdasarkan hal tersebut, maka dapat disimpulkan bahwa pembelajaran menggunakan model pembelajaran inkuiri terbimbing dapat mendorong keterlaksanaan RPP dengan sangat baik.

Kepraktisan juga dilihat dari respon siswa. Hasil analisis respon siswa pada uji lapangan menunjukkan bahwa respons positif yang diberikan oleh siswa pada uji lapangan kelas VIIC adalah $100 \%$ menyatakan senang dan berminat. Rata-rata skor respon siswa tertarik terhadap perangkat pembelajaran LKS adalah $100 \%$, respon siswa yang menyatakan perangkat pembelajaran LKS adalah hal baru adalah $70 \%$. respon siswa yang menyatakan kegiatan pembelajaran yang dilatihkan mudah dipahami adalah $3 \%$, dan siswa yang merasa berminat mengikuti kegiatan pembelajaran menggunakan inkuri terbimbing adalah $100 \%$. Hasil tersebut berarti bahwa siswa menganggap proses pembelajaran dilaksanakan secara menyenangkan.

Siswa memberikan respon yang baik terhadap kegiatan pembelajaran, hal ini karena siswa merasa sangat tertarik terhadap pembelajaran berorientasi inkuiri terbimbing dan menginginkan agar kegiatan pembelajaran dapat membangkitkan motivasi dan keinginan rasa ingin tahu. Hasil penelitian ini sejalan dengan penelitian yang telah dilakukan oleh Jaya, dkk (2014) bahwa respon positif yang diberikan oleh siswa terhadap pembelajaran yang telah dilakukan disebabkan karena ketertarikan siswa terhadap metode yang digunakan dalam pembelajaran dalam inkuiri memberikan pengalaman langsung pada siswa dimulai dari mengamati, mengajukan pertanyaan tentang informasi yang tidak dipahami, mengumpulkan informasi/eksperimen, mengasosiasi atau mengolah informasi, dan mengkomunikasikan hasil yang diperoleh.

Berdasarkan hal tersebut, maka dapat disimpulkan bahwa pembelajaran menggunakan model pembelajaran inkuiri terbimbing dapat membuat pelajaran 
jadi menyenangkan bagi siswa. Sehingga merupakan suatu kelebihan pada penelitian ini yaitu dapat membuat minat siswa terhadap pembelajaran menjadi lebih baik.

\section{Keefektivan perangkat pembelajaran}

Penelitian ini telah menghasilkan perangkat pembelajaran yang efektif karena semua indikator keefektifan telah terpenuhi yaitu: 1) hasil penilaian kognitif (pre test -pos test), dan 2) hasil penilaian keterampilan proses sains siswa. Analisis efektivitas perangkat pembelajaran diperoleh melalui data hasil belajar kognitif produk, dan keterampilan proses sains. Deskripsi hasil analisis efektivitas perangkat pembelajaran pada uji pemakaian disajikan sebagai berikut.

Keefektifan perangkat pembelajaran diukur dengan memberikan tes kognitif yang terdiri dari 10 soal objektif untuk setiap pertemuan. Penilaian kognitif diberikan pada awal sebelum pembelajaran pertemuan pertama dimulai (pre test) dan akhir pertemuan (post test). Setelah rangkaian pertemuan dilaksanakan, nilai kognitif siswa saat pretes rata-rata 63,19 (Kategori D)dari 35 siswa mencapai ketuntasan klasikal sebanyak 25,71\%. Rendahnya persentase siswa yang tuntas pada kegiatan pretes disebabkan siswa masih belum memahami konsep yang akan diajarkan dan belum terbiasa mengikuti pembelajaran dengan model inkuiri terbimbing. Setelah dilakukan pembelajaran menggunakan model inkuiri terbimbing sebanyak empat kali pertemuan nilai rata-rata pada saat post test meningkat menjadi 93,19 (kategori A) dengan ketuntasan klasikal sebesar $100 \%$ Hal ini menunjukkan bahwa pembelajaran menggunakan model inkuiri terbimbing dapat meningkatkan nilai kognitif produk pada siswa.

Hasil penelitian ini sejalan dengan penelitian yang telah dilakukan oleh Yenny, (2014) menyatakan bahwa nilai tertinggi siswa kelas inkuiri terbimbing lebih tinggi dari siswa pada kelas konvensional, nilai terendah maupun nilai ratarata keseluruhan inkuiri terbimbing juga lebih tinggi. Temuan hasil penelitian ini, juga sejalan dengan penelitian yang dilakukan sebelumnya oleh Jaya, dkk. (2014) bahwa proses kegiatan pembelajaran dengan menggunakan model pembelajaran inkuiri terbimbing dapat menimbulkan ketertarikan siswa mempelajari materi pelajaran dan meningkatkan hasil belajar siswa.

Hasil penilaian keterampilan proses sains siswa menunjukkan bahwa ratarata nilai semua indikator KPS sebesar 81,46 dengan kategori 'B' (baik). nilai keterampilan proses sains siswa mengalami peningkatan disetiap proses pembelajaran, pada pertemuan pertama nilai rata-rata sebesar 73,66 dengan kategori D” (kurang) dan meningkat pada pertemuan terakhir dengan nilai ratarata 87 dengan kategori "B" (baik). Sehingga dapat disimpulkan bahwa model pembelajaran inkuiri terbimbing yang dikembangkan efektif untuk meningkatkan keterampilan proses sains siswa. Hal tersebut sesuai dengan pendapat Gulo (2002) dalam Trianto (2009:166) menyatakan strategi inkuiri berarti suatu rangkaian kegiatan yang melibatkan secara maksimal kemampuan siswa untuk mencari dan menyelidiki secara sistematis, kritis, logis dan analitis, sehingga mereka dapat merumuskan sendiri penemuannya dengan penuh percaya diri. 


\section{KESIMPULAN}

Penelitian dan pengembangan perangkat pembelajaran yang meliputi silabus, RPP, LKS pada konsep Pencemaran Lingkungan di SMP Negeri 27 Sungai Andai Banjarmasin berbasis inquiri telah memenuhi indikator kevalidan dengan revisi kecil, kepraktisan dan keefektifan serta dapat digunakan dalam pembelajaran di sekolah.

\section{SARAN}

Demi kesempurnaan hasil penelitian dan pengembangan yang telah didapatkan, diharapkan bagi peneliti berikutnya dapat meneruskan penelitian di sekolah yang berbeda dan mengembangkan lebih lanjut khususnya perangkat tes hasil belajar dan tes keterampilan proses sains serta bahan ajar pada konsep yang sama ataupun konsep yang lain. Bagi guru dapat memanfaatkan dalam menyusun dan mengembangkan perangkat pembelajaran biologi dengan konsep yang berbeda.

\section{DAFTAR PUSTAKA}

Arifin, Z. 2011. Konsep dan Model Pengembangan Kurikulum. Bandung: PT. Remaja Rosdakarya.

Akbar, S. 2013. Instrumen Perangkat Pembelajaran (A. Holid, Ed). Bandung: Remaja Rosdakarya.

Dewi,K.,dkk (2013). Pengembangan Perangkat Pembelajaran IPA Terpadu Dengan Setting Inkuiri Terbimbing Untuk Meningkatkan Pemahaman Konsep dan Kinerja Ilmiah Siswa. e-journal Program Pasca Sarjana Universitas Pendidikan Genesha Program Studi Pendidikan IPA (Volume 3 Tahun 2013).

Dimyanti, Modjiono, 2013. Belajar dan Pembelajaran. Jakarta : Rineka Cipta.

Elok Sudibyo, (2005), Respon Siswa SLTP Khodijah Surabaya Terhadap Kegiatan

Ujicoba Perangkat Pembelajaran IPA Terpadu, JURNAL PENDIDIKAN DASAR, VOL. 6, NO. 2, 2005: $61-118$

Hamiyah dan Zauhar. 2014. Strategi Belajar Mengajar di Kelas. Jakarta. PrestasiPustakaraya.

Jaya, I.M, I.W. Sadia, dan I.B.P. Arnyana. 2014 Pengembangan Perangkat Pembelajaran Biologi Bermuatan Pendidikan Karakter Dengan Setting Guided Inquiry Untuk Meningkatkan Karakter Dan Hasil Belajar Siswa SMP. e-Journal Program Pascasarjana Universitas Pendidikan Ganesha Program Studi IPA (Volume 4 Tahun 2014). http://www.unesa.ac.id/bank/jurnal/.pdf, diambil 21 April 2014 Page 119 
Kemendikbud No 53 Tahun 2015. Penilaian Hasil Belajar Oleh Pendidik PadaPendidikan Dasar Dan Pendidikan Menengah. (Online: http://3$\underline{\text { Panduan Untuk-SMA-Final/171215-pdf. Diatas pukul } 09.00 \text { Tanggal } 1}$ Juni 2016.

Kunandar. 2013. Penilaian Autentik (Penilaian Hasil Peseta Didik BerdasarkanKurikulum 2013). PT RajaGrafindo Persada. Jakarta.

Lawson, A. E. 1995. Science Teaching and The Development of Thinking. California : Wadswort.

Nur, Mohammad dan Prima Retno Wikandari. 2013. Pengajaran Berpusat KepadaSiswa dan Pendekatan Konstruktivis dalam Pengajaran. Pusat Studi Matematika Dan IPA Sekolah: Universitas Negeri Surabaya.

Putra, Sitiatava Rizema. 2013. Desain Belajar Mengajar Kreatif Berbasis Sains. Jogjakarta: Diva Press.

Sanjaya, W. 2010. Kurikulum dan Pembelajaran Teori dan Praktik Pengembangan Kurikulum Tingkat Satuan Pendidikan (KTSP). Jakarta: Kencana Prenada Media Group.

Sudjana, Nana, 1990. Penilaian Hasil Proses Belajar Mengajar. Bandung : Remaja Rosdakarya Offest.

Sugiono,(2009). Metode Penelitian Kualitatif Kuantitatif, dan $R \& D$. Bandung: Alfabeta.

Suhadi. 2007. Penyusunan Perangkat Pembelajaran dalam Kegiatan Lesson Study. Makalah disampaikan pada Pelatihan Lesson Study untuk Guru SMP se-Kabupaten Hulu Sungai Utara. Hulu Sungai Utara, Kalimantan 27-31 Mei 2007.

Trianto. 2009. Mendesain Model Pembelajaran Inovatif-Progresif. Jakarta:Prenada Media.

Usman, U. 2011. Menjadi Guru Profesional. Bandung: PT. Remaja Rosdakarya

Wiryanti, 2013. Pengembangan Perangkat Pembelajaran Biologi Berbasis Nature Of Science (Nos) Untuk Meningkatkan Pengetahuan, Keterampilan Proses Sains dan Sikap Ilmiah Siswa Sma Kelas X. Universitas Pendidikan Ganesha Singaraja, Indonesia.

Zuhdan, 2011. Pengembangan Perangkat Pembelajaran Sains Terpadu Untuk Meningkatkan Kognitif, Keterampilan Proses, Kreativitas Serta Menerapkan Konsep Ilmiah Peserta Didik SMP. Program Pascasarjana Universitas Negeri Yogyakarta. Yogyakarta 2011 